\title{
Design and Validation of Teaching Instruments Oriented Problem Solving to Train Students' Metacognitive Skills
}

\author{
Dian Avina Turja Soffa* \\ Science Education Program, Postgraduate School \\ Universitas Negeri Surabaya \\ Surabaya, Indonesia \\ diansoffa16070795032@mhs.unesa.ac.id
}

\author{
Sri Poedjiastoeti, Pirim Setiarso \\ Department of Chemistry \\ Universitas Negeri Surabaya \\ Surabaya, Indonesia
}

\begin{abstract}
This research aims to develop a valid teaching instrument. The developed teaching instruments oriented problem solving to train students' metacognitive skills at acid base titration topic. The specifications of instruments included the syllabus, lesson plans, student worksheets, and tests. The problem-solving model have four steps. The steps as followed understand the problem, devise a plan, carry out the plan, and look back. The indicators metacognitive skills namely planning, monitoring, and evaluating. Research design of teaching instruments used Research and Development design (R\&D) from Sukmadinata. Validation data were obtained from experts assessment used validity instrument. The data were analysed using Likert scale. Based on the expert assessment, the teaching instruments were developed valid, reliable and can be used in learning with little revision.
\end{abstract}

Keywords-Validity, teaching instruments, problem solving, metacognitive skills, acid base topic.

\section{INTRODUCTION}

In this information technology era, thinking and problem solving skills are very important for students to masters knowledge. Schools play a major role in training students to develop their thinking skills. Primary goal of education is make students thinking effectively. Thinking skills help students to choose the strategy to solve the problem [1].

Thinking about one's own thinking and how someone learns and solve the problems are describe as metacognition. Metacognition have three dimensions. There are knowledge about one's own, knowledge about the thinking process, and controlling of commitment, attitude, and attention to learn new or complex task [2]. Metacognitive activities grouped at three categories: planning, monitoring, and evaluating [3].

Planning is a selection of appropriate strategies and allocation of resources that affect to performances. Monitoring is a one's on-line awareness of comprehension and task performance. Evaluation is an appraising the products and regulatory processes of one's learning. Regulatory processes including planning, monitoring, and evaluating may not be conscious in many learning situation [4].

Metacognition is important to regulate and improve students cognitive skills and strategies used in problem solving process. Metacognitive skills is related to the students problem solving ability. Problem solving is acknowledge as a paradigm of complex cognition that is part of everyday experience. Problem solving as a subsequent application of certain methods or strategies in order to move from current state to a goal state There is a strong correlation between problem solving and metacognition. The students have a higher level of metacognitive skills become successful in problem solving [5].

Problem solving strategy consisting of four major steps as follows: understanding the problem, devising a plan, carrying out the plan, and examine the solution [6]. It is needed to have the knowledge for the solving and successful resolution. When students encounter with failures in problem solving technique, control skills (metacognition) will be helpful for applying strategies successfully [7].

Some fundamentals principles of learning guide all teaching strategies, focused on higher order or lower order thinking. These principles suggest that learning is a individual activity. Goals and learning task that are meaningful for one teacher or students may not be meaningful for another. So, to increase students thinking skills, teacher must motivate students to learn too [8].

One of teachers way to motivate the students is develop teaching instruments. Teaching instrument is a media which help and facilitate learning process to achieve the goal [9]. The specifications of teaching instruments included the syllabus, lesson plans, student worksheets, and tests. The instruments must be appropriate with validity criteria in order to valid and can be use in learning [10].

Based on the statement above, the researcher will develop teaching instruments orienting problem solving to train metacognitive skills. The topic of the instruments is acid base titration. This topic teach on $11^{\text {th }}$ grade senior high school students.

\section{METHODS}

The research developed the teaching instrument oriented problem solving to train students' metacognitive skills. The teaching instrument included syllabus, lesson plans, student worksheets, and tests. Research design of teaching instruments used Research and Development design (R\&D) from Sukmadinata (2015). The R\&D design have three steps as follow: preface study, development study, and trial. In this research limited to preface study steps.

Preface study included literature study, field study and teaching instrument design and layout. Literature study have 
to know information about acid base titration topic, problem solving process, and metacognitive skills. Field study have to know information about learning problem, and students' metacognitive skills. Teaching instrument design and layout was an activity to design the teaching instrument and validated the teaching instruments.

Validation teaching instruments was an expert assessment used validation instrument with Likert scale. Validator was three expert, two lecturers and one teacher. The validity data used to know quality the teaching instruments. The validity data was analysed using teaching instruments validation criteria in Table 1 .

TABLE I. TEACHING INSTRUMENT VALIDATION CRITERIA

\begin{tabular}{|c|c|c|}
\hline Score interval & Category & Explanation \\
\hline $\mathbf{3 . 5} \leq \mathbf{V} \leq \mathbf{4 . 0}$ & Very valid & $\begin{array}{c}\text { Can be used without } \\
\text { revision }\end{array}$ \\
\hline $\mathbf{2 . 9} \leq \mathbf{V} \leq \mathbf{3 . 4}$ & Valid & $\begin{array}{c}\text { Can be used with a few } \\
\text { revision }\end{array}$ \\
\hline $\mathbf{1 . 7} \leq \mathbf{V} \leq \mathbf{2 . 8}$ & Less valid & $\begin{array}{c}\text { Can be used with many } \\
\text { revisions }\end{array}$ \\
\hline $\mathbf{1 . 0} \leq \mathbf{V} \leq \mathbf{1 . 6}$ & Invalid & $\begin{array}{c}\text { Not yet in use and } \\
\text { requires consultation }\end{array}$ \\
\hline
\end{tabular}

The reliability of validation teaching instrument was calculated based on the similarity of values given by three validators. So, the percentage of agreement was a similarity value about validator 1 and 2 ; validator 1 and 3 ; and validator 2 and 3 with the formula:

Percentage of Agreement $=\left(1-\left[\frac{A-B}{A+B}\right]\right) \times 100 \%$

Information:

$\mathrm{A}=$ Highest score given by the validator

$\mathrm{B}=$ Lowest score given by the validator

Based on Table 1 above it can be seen that a teaching instruments is valid if got a score $\geq 2,9$. Then the assessment of instrument was reliable if the percentage of agreement obtained is $\geq 75 \%$ [11].

\section{RESULT AND DISCUSSION}

\section{A. Results}

Validation of learning devices developed included validation of syllabus, lesson plan, student worksheets, and tests. The teaching instruments developed in this study was valid for use in the learning process when got minimum score of $\geq 2.9$.

1) Analysis of syllabus validation results: The validation of syllabus on acid base titration topic have five aspects. The aspects as follows: identity, suitability of the syllabus with the curriculum, suitability of indicators with basic competencies, suitability learning process with indicators and suitability of assessment instruments. The validation results have been analyzed and got average score $3.67-4$. This results means that the syllabus in very valid category.

The percentage of agreement of the validation results was $85,71 \%-100 \%$. Means that the assessment of syllabus was reliable. The validation and reliability results of syllabus can be seen in the following table.

TABLE II. VALIDATION RESULTS OF SYLLABUS

\begin{tabular}{|c|c|c|c|}
\hline Aspect & $\begin{array}{c}\text { Average } \\
\text { score }\end{array}$ & Category & $\begin{array}{c}\text { Percentage of } \\
\text { agreement (\%) }\end{array}$ \\
\hline Identity & 3.67 & Very valid & $85.71-100$ \\
\hline $\begin{array}{c}\text { Suitability with the } \\
\text { curriculum }\end{array}$ & 4 & Very valid & 100 \\
\hline $\begin{array}{c}\text { Suitability of indicators } \\
\text { with basic competencies }\end{array}$ & 3.67 & Very valid & $85.71-100$ \\
\hline $\begin{array}{c}\text { Suitability learning process } \\
\text { with indicators }\end{array}$ & 3.67 & Very valid & $85.71-100$ \\
\hline $\begin{array}{c}\text { Suitability of assessment } \\
\text { instruments }\end{array}$ & 3.67 & Very valid & $85.71-100$ \\
\hline
\end{tabular}

2) Analysis of lesson plan validation results: The lesson plan oriented problem solving and to trained metacognitive skills. The topic of lesson plan was acid base titration topics. The lesson plans consists of three meetings, every meeting consist of $3 \times 45$ minutes or 3 lesson time. The validation aspects as follows: identity, learning objectives, learning materials, facilities and learning resources, learning plan, evaluation, and language. The provision of wrote lesson plan refers to $22^{\text {nd }}$ Permendikbud 2016. The validation results can be seen in the following table.

\section{TABLE III. VALIDATION RESULT OF LESSON PLAN}

\begin{tabular}{|c|c|c|c|}
\hline Aspect & $\begin{array}{c}\text { Average } \\
\text { score }\end{array}$ & Category & $\begin{array}{c}\text { Percentage of } \\
\text { agreement (\%) }\end{array}$ \\
\hline Identity & 3.67 & Very valid & $85.71-100$ \\
\hline Learning objectives & 3.67 & Very valid & $85.71-100$ \\
\hline Learning materials & 3.50 & Very valid & $85.71-100$ \\
\hline $\begin{array}{c}\text { Facilities and } \\
\text { learning resources }\end{array}$ & 3.58 & Very valid & $85.71-100$ \\
\hline Learning plan & 3.59 & Very valid & $85.71-100$ \\
\hline Evaluation & 3.67 & Very valid & $85.71-100$ \\
\hline Language & 3.33 & Valid & $85.71-100$ \\
\hline
\end{tabular}

Based on Table 3 the lesson plan validation results from three validators obtained an average score of $3.33-3.67$ with valid - very valid category. This means that the lesson plan compiled by researchers could be used as a learning tool with little revision. The percentage of agreement of the validation results was $85,71 \%-100 \%$. Means that the assessment of lesson plan was reliable.

3) Analysis of student worksheets validation results: Student worksheets was developed orientated problem solving and to trained metacognitive skills. The topic of students worksheets was acid base titration. The first meeting discussed neutralization reactions, the second meeting discussed acid base titration, and the third meeting discussed titration curved. This validation based on criteria was adapted from Depdiknas (2008) [12]. The validation results can be seen in the following table.

TABLE IV VALIDATION RESULT OF STUDENT WORKSHEET

\begin{tabular}{|c|c|c|c|}
\hline Aspect & $\begin{array}{c}\text { Average } \\
\text { score }\end{array}$ & Category & $\begin{array}{c}\text { Percentage of } \\
\text { agreement (\%) }\end{array}$ \\
\hline Content criteria & 3.56 & Very valid & $85.71-100$ \\
\hline Language criteria & 3.28 & Valid & $85.71-100$ \\
\hline Presentation criteria & 3.59 & Very valid & $85.71-100$ \\
\hline Graphical criteria & 3.58 & Very valid & $85.71-100$ \\
\hline
\end{tabular}

Based on Table 4, the validation results obtained an average score of $3.28-3.59$. This means that the student worksheets categorized into valid - very valid categories and can be used as a learning tool with little revision. The percentage of agreement of the validation results was 
$85,71 \%-100 \%$. Means that the assessment of student's worksheets was reliable.

4) Analysis of test validation results: The test was developed constitute concept mastery test and metacognitive skills test. The test formed of six questions essay test. This question developed refers to indicators of metacognitive skills. The indicators was namely planning, monitoring, and evaluating [4]. The topic of test was acid base titration. Validated aspects of the tests include content, language and writing components. The results of the validation of critical thinking skills tests were presented in Table 5.

TABLE V VALIDATION RESULT OF TESTS

\begin{tabular}{|c|c|c|c|}
\hline Aspect & $\begin{array}{c}\text { Average } \\
\text { score }\end{array}$ & Category & $\begin{array}{c}\text { Percentage of } \\
\text { agreement (\%) }\end{array}$ \\
\hline Content & 3.61 & Very valid & $85.71-100$ \\
\hline $\begin{array}{c}\text { Writing and } \\
\text { Language }\end{array}$ & 3.67 & Very valid & $85.71-100$ \\
\hline
\end{tabular}

Table 5 describes the validation results of tests instruments. The average score obtained is $3.61-3.67$ with very valid criteria. Means that test instrument in the form of six essay questions could be used to determine the extent of students' metacognitive skills and concept mastery with a little revision. The percentage of agreement of the validation results was $85,71 \%-100 \%$. Means that the assessment of students worksheets was reliable.

\section{B. Discussion}

The aim of this study was to develop and validate instrument of high quality to train metacognitive skills oriented problem solving. The teaching instruments have developed must valid, reliable and can be used in learning. This instruments provided teachers with a tool that will gave them a deeper understanding about problem solving activities, and can provided information that may improved students outcomes [3].

Each teaching instruments contained problem solving steps as follows: understanding the problem, devising a plan, carrying out the plan, and examine the solution [6]. Understanding the problem by identified the unknown, data, and condition. Devising a plan was a solver seeks about connection between data and the unknown. Carrying out the plan was a carried out the plan on step two, and each plan must be checked for correctness. Looking back was a examined the problem solution and checked the arguments [5].

Problem solving strategy steps was important for students to use while solving problems. Problem solving steps was effective in metacognitive learning. The majority of research accepted that metacognitive skills that consist of planning, monitoring and evaluating re [5]. According to Arthur (2015), implementation of problem solving strategy was able to improved students' learning achievement. Problem solving was a process that emphasized the importance of procedure, measure and strategy by students in the process to find a solution [13]. Problem solving activity can opened opportunities for students to learn freely. The benefits of problem solving as educational tool has long been known, appreciating the skills, techniques and procedures required for effective problem solving have not been adequately taught specifically [14].
In every problem solving steps included metacognitive skills, namely planning, monitoring, and evaluating [4]. Metacognitive skills were very needed to successful learning. Metacognitive skills may help students organized the own cognitive skills and can be seen the own cognitive drawback, so the students could make a remedial activity [15]. An individual who has a metacognitive skill, could monitor, plan and execute every step in thinking process. Therefore, the efficiency and quality of learning can be increased [16]. Based on the explanation above, can be seen that problem solving strategy related to metacognitive skills.

The teaching instrument topic was acid base titration. These topics related to other topics such as acid base, salt hydrolysis, buffer solution, and stoichiometry [17]. Acid base titration topic related with metacognitive activity such as measurement and conversion, physical and chemical changes, and mole concept [2]. The topic was divided to three subtopics, namely neutralization reaction, acid base titration, and titration curved. First subtopic about neutralization reaction, in this topic student must understood this reaction and can explained the reaction. Second subtopic about acid base titration, in this topic student must understood acid base reaction, measured $\mathrm{pH}$, substance concentration, designed and presented acid base titration experiment, and analyzed the data. The last subtopic about titration curve, in this topic student must understood acid base reaction, measured $\mathrm{pH}$, substance concentration, made and analyzed titration curved. Based on these explanation, Metacognitive skills related to acid base titration topic.

The validation of syllabus, lesson plan, student worksheets, and tests explained as follow. Syllabus was a reference to arranged the learning framework to every substance subject. The validation of syllabus on acid base titration topic have five aspects. The aspects as follows: identity, suitability of the syllabus with the curriculum, suitability of indicators with basic competencies, suitability learning process with indicators and suitability of assessment instruments [18]. The syllabus validation data, based on Table 2 have an average score $3.67-4$ with a very valid category.

The results mean that the syllabus developed base on 2013rd curriculum standards. This syllabus appropriated with problem solving strategies to train students' metacognitive skills at acid base titration topics. The percentage of agreement of the validation syllabus results was $85,71 \%-100 \%$. Means that the assessment of syllabus was reliable. The developed syllabus could be used as a reference for developing lesson plan, student worksheets, and tests with minor revisions.

Lesson plan was a plan of learning activity meeting. The teachers must arrange the lesson plan systematics and comprehensive. The lesson plan was developed based on 2013rd curriculum, syllabus and learning text book. The validation aspects of lesson plan as follows: identity, learning objectives, learning materials, facilities and learning resources, learning plan, evaluation, and language [18].

Based on Table 3 the lesson plan validation results from three validators obtained an average score of $3.33-3.67$ with valid - very valid category. This means that the lesson plan compiled by researchers could be used as a learning tool with little revision. The lesson plan suitability with 
2013rd curriculum included syllabus, basic competencies, indicators, and learning outcomes. The lesson plan also suitability with problem solving strategies, metacognitive skills, and acid base titration topic. The percentage of agreement of the validation results was $85,71 \%-100 \%$. Means that the assessment of lesson plan was reliable.

Another teaching instrument have developed was student worksheets. Student worksheets was a task sheet for students must be done. This worksheet consists of instructions and procedures to have done a task. The validation aspects of student worksheets as follows: content, language, presentation and graphical criteria. Content criteria consist of suitability with main and basic competencies, suitability with student development, suitability with the topics, and suitability with problem solving and metacognitive skills. Language criteria consist of information clarity, suitability with Indonesian language, and effective and efficient language. Presentation criteria consist of list of the content, motivation, completeness information. Graphical criteria consist of kind and size of font, lay out, illustration, pictures, and photo [12].

Based on Table 4, the validation results obtained an average score of 3.28 - 3.59 categorized into valid - very valid categories. Means that the student worksheets can be used as a learning tool with little revision. The students worksheets suitability with 2013rd curriculum included syllabus, main and basic competencies, indicators, and learning outcomes. The students worksheets also suitability with problem solving strategies, metacognitive skills, and acid base titration topic. The students worksheet was increased motivation and interesting. The percentage of agreement of the validation results was $85,71 \%-100 \%$. Means that the assessment of students worksheets was reliable.

The last teaching instrument was test. The test was an assessment to collected information about students and class to decide in learning. The assessment was a continuous process. The effective assessment always bound with learning [19]. In this research, the test was developed to measured concept mastery test and metacognitive skills test. The test consists of six essay questions about acid base titration topic and three aspects of metacognitive skills. Validated aspects of the tests included content, language and writing components. This test is equipped with a rubric or answer grid to facilitate the teacher in the assessment process.

The test validation data, based on Table 5 , have average score obtained is $3.61-3.67$ with very valid criteria. Means that test instrument in the form of six essay questions could be used to determine the extent of students' metacognitive skills and concept mastery with a little revision. The test was developed suitability with problem solving, metacognitive skills and acid base titration topic. These test was clarity, suitability with Indonesian language, and used effective and efficient language. The test suitability with learning outcomes and indicators. The percentage of agreement of the validation results was $85,71 \%-100 \%$. Means that the assessment of students worksheets was reliable.

Based on the results, the teaching instrument has developed valid and reliable. These instruments can be used in learning with a little revision. The teaching instruments suitability with 2013rd curriculum. The teaching instruments also suitability with problem solving strategies, metacognitive skills, and acid base titration topic. The teaching instruments was increased motivation and interesting. The teaching instruments was clarity, suitability with Indonesian language, and used effective and efficient language.

\section{CONCLUSIONS}

Based on the results of the research and discussion, can be concluded that the teaching instruments was developed oriented problem solving to train metacognitive skills at acid base titration topic. The instruments was developed include syllabus, lesson plans, student worksheets, and tests. The teaching instruments were valid and reliable. Means that can be used in the learning process with little revision.

\section{ACKNOWLEDGMENT}

Thanks to three validators Mr. Bambang Sugiarto and Mrs Utiya Azizah from Department of Chemistry, Universitas Negeri Surabaya, and Mr. Dwi Bagus Rendy from Muhammadiyah 4 Senior High School Surabaya for help the research to validation the teaching instruments.

\section{REFERENCES}

[1] T. K. Ngang, S. Nair, and B. Prachack, "Developing Instruments to Measure Thinking Skills and Problem Solving Skills among Malaysian Primary School Pupils," Procedia Social and Behavioral Science, vol. 116, pp 3760 - 3764, 2014

[2] R. Pulmones, "Learning Chemistry in a Metacognitive Environment," The Asia Pacific-Education Research, vol. 16:2, pp 165 - 183, 2007

[3] M. Cooper and S. Sandi-Urena, "Design and validation of an instrument to assess metacognitive skillfulness in chemistry problem solving," Research: Science and Education, Journal of chemical Education, vol. 86:2, pp 240 - 245, 2009

[4] G. Schraw and D. Moshman, "Methacognitive Theories," Educational Phsychology Review, vol. 7:4, pp 351-371, 1995

[5] T. Gok, "The General Assessment Of Problem Solving Processes And Metacognitive In Physics Education," Eurasian Journal of Physics and Chemistry Education, vol. 2:2, pp 110 - 122, 2010

[6] G. Polya, "How To Solve It," New Jersey: Princenon University Press, 1973

[7] J. Dostal, “ Theory of Problem Solving," Procedia Social and Behavioral Science, vol. 174, pp 2798 - 2805, 2015

[8] King, Goodson, and Rohani, "High order Thinking Skills," The Center for Advancement of Learning and Assessment, pp 7-117, 2013

[9] M Ibrahim, "Pengembangan Perangkat Pembelajaran (Pelatihan Terintegrasi Berbasis Kompetensi Guru Mata Pelajaran Biologi)," Jakarta : Depdiknas, 2003

[10] T. Plomp and N. Nieveen, "An Introduction to Educational Research," Netherlands : SLO, 2010

[11] G. Borich, "Observation Skill for Effective Teaching," New York : Mac Millan Publishing Company, 1994

[12] Depdiknas, "Panduan Pengembangan Bahan Ajar," Jakarta Depdiknas, 2008

[13] R. Arthur, "Achievement of The Civil Engineering Evaluation Program," American Journal of Educational Research, vol. 3:8, pp 946-967, 2015

[14] J. Surif, N. H. Ibrahim, and M. Mokhtar, "Conceptual and Procedural Knowledge in Problem Solving," Procedia Social and Behavioral Science, vol. 56, pp 416 - 425, 2012

[15] S. Imel, "Metacognitive skills for adult learning," ERIC Publication no. 39,2002

[16] M. Tuncer and F. Kaysi, "The Development of Metacognitive Thinking Skills Scale," International Journal of Learning \& Development, vol. 3:2, pp 70 - 76, 2013

[17] R. Chang and J. Overby, " General Chemistry: The Essential Concepts," New York : Mc Graw Hill, 2011 
[18] Mendikbud, "Permendikbud No 22 Tahun 2016 tentang Standar Penilaian Pendidikan," Jakarta : Kemendikbud, 2016
[19] R. L Arends, "Learning to Teach,” New York : Mc Graw Hill, 2009 